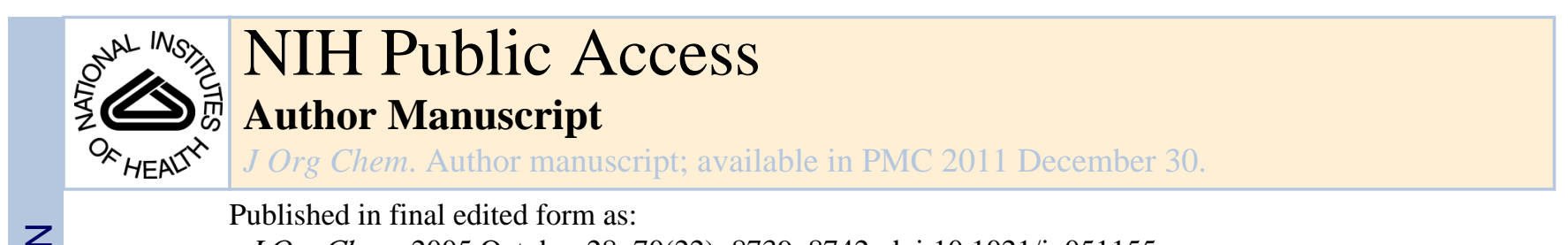

J Org Chem. 2005 October 28; 70(22): 8739-8742. doi:10.1021/jo051155y.

\title{
A Model Study Toward the Total Synthesis of $\mathrm{N}$ - Deacetyllappaconitine
}

\author{
Douglass F. Taber ${ }^{*}$, Jiang-Lin Liang, Bei Chen, and Lisi Cai \\ Department of Chemistry and Biochemistry, University of Delaware, Newark, DE 19716
}

\begin{abstract}
A model study leading to the preparation of the AEF rings of $N$-deacetyllappaconitine is described. The conjugate addition to the $\alpha$-alkyl cyclohexenone $\mathbf{1 0}$ proceeded with high diastereocontrol. The Mannich cyclization of $\mathbf{1 6}$ to $\mathbf{4}$ was accomplished by heating with Rexyn-300 and $\mathrm{Na}_{2} \mathrm{SO}_{4}$.
\end{abstract}

\section{Introduction}

The hexacyclic $N$-deacetyllappaconitine $\mathbf{1}$ is a cardioactive agent that is representative of the diterpenoid Delphinium alkaloids. ${ }^{1}$ This intriguing skeleton, which includes six rings and twelve stereogenic centers, is a substantial challenge for organic synthesis. Despite the potent physiological activity of this class of alkaloids, ${ }^{2}$ only a little progress ${ }^{3}$ has been reported toward a practical preparation of this family of alkaloids since the landmark (56 steps) synthesis of the first aconite by Wiesner ${ }^{4}$ more than 25 years ago.

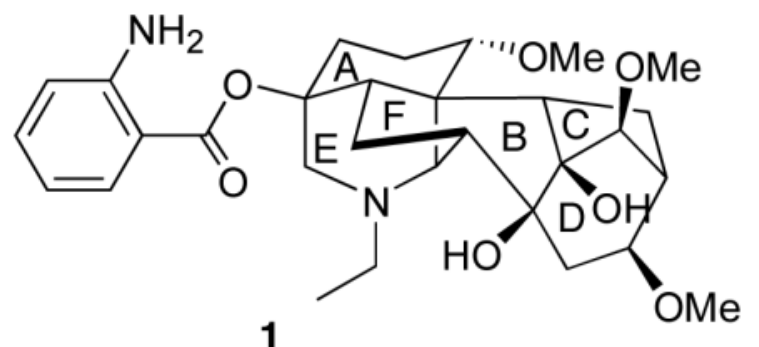

The intramolecular Mannich reaction is a powerful strategy for the assembly of complex ring systems. ${ }^{5}$ For the synthesis of the diterpene alkaloid $\mathbf{1}$ (Scheme 1), our plan is to use a tandem aldol / Mannich cyclization $(\mathbf{3} \rightarrow \mathbf{2})$ as the key step. In order to explore the proposed Mannich cyclization, we have carried out a model study $(\mathbf{5} \rightarrow \mathbf{4})$ using an isopropyl group as a surrogate for the right bicyclic fragment of $\mathbf{3}$. The compound $\mathbf{4}$ incorporates the A, E and F rings of $\mathrm{N}$-deacetyllappaconitine.

\section{Results and Discussion}

\section{Intramolecular Alkylidene Carbene Insertion to Form 10}

The route toward the Mannich precursor 5 began with the phosphonium salt 6 (Scheme 2), which is easily prepared in large scale from racemic 1,2,4-butanetriol (both

taberdf@udel.edu.

Supporting Information Available: General experimental procedures, experimental procedures for the preparation of $\mathbf{7}$ through $\mathbf{1 0}$, and ${ }^{1} \mathrm{H}$ and ${ }^{13} \mathrm{C}$ NMR spectra for all new compounds. This material is available free of charge via the Internet at http://pubs.acs.org. 
enantiomerically-pure 1,2,4-butanetriols are also commercially available). ${ }^{6}$ Recently, we reported the preparation of ketones by the condensation of phosphonium salts with nitriles, 7 following an improvement of the McEwen procedure. ${ }^{8} \mathrm{We}$ have since found (Supporting Information) that including an additional stoichiometric amount of LiI improved the yield of the ketone 7 from $61 \%$ to $84 \%$. The ketone 7 was cyclized via intramolecular alkylidene carbene $\mathrm{C}-\mathrm{H}$ insertion to give $\mathbf{8} .{ }^{9}$ Ozonolysis followed by aldol condensation then gave the cyclohexenone $\mathbf{1 0 .}$

\section{Conjugate Addition to the $\alpha$-Alkyl Cyclohexenone $\mathbf{1 0}$}

Several years ago, we reported that excellent diastereoselectivity could be achieved for the chlorotriethylsilane-promoted conjugate addition of cuprates to the cyclohexenone $\mathbf{1 2}$ to give 13 (Scheme 3, diastereomer ratio 93:7). ${ }^{10}$ The presence of the alkyl group on the $\alpha$ position of the enone makes the conjugate addition to $\mathbf{1 0}$ more difficult. To our delight, $\mathrm{Cu}-$ mediated addition of the Grignard reagent derived from 4-bromo-1-butene proceeded smoothly to give $\mathbf{1 1}$ as a single diastereomer, in $78 \%$ yield from $\mathbf{1 0}$, under the same conditions as described before. The relative configuration achieved was that needed for the Mannich cyclization. This unique conjugate addition forms two stereocenters in one step with high stereoselectivity. Thus, intramolecular carbene insertion and conjugate addition combine to form a powerful approach for the stereoselective synthesis of such multisubstituted cyclohexanones.

\section{Mannich Cyclization}

With the correct relative congifuration of $\mathbf{1 1}$ in hand, deprotection (Scheme 4) with trifluoroacetic acid (TFA) gave the diol 14, as an inconsequential mixture of two diastereomers. Monotosylation of 14 afforded 15. Ozonolysis of 15 gave an aldehyde, that subsequently cyclized with the tertiary alcohol to form a hemiacetal intermediate. This intermediate was used for the Mannich cyclization without further purification.

Our initial attempts at Mannich cyclization were not encouraging. On exposure to ethylamine, the hemiacetal was converted to the Mannich base $\mathbf{1 6}(90 \%)$, but only a trace amount of the desired product 4 (2\%) could be isolated. Dehydration of the Mannich base 16 to form the cyclized product $\mathbf{4}$ proved elusive. TsOH is a very efficient reagent for the intermolecular Mannich reaction, ${ }^{11}$ but no reaction was observed even when a stoichiometric amount of $\mathrm{TsOH}$ was added to 16, with or without heating. Lewis 12 acids, such as $\mathrm{LiClO}_{4}$ or $\mathrm{Al}(\mathrm{Et})_{2} \mathrm{Cl}$, can prompt a Mannich base to form the cyclized product. However, Lewis acids also did not effect the dehydration of $\mathbf{1 6 .}$

Fortunately, we found that Rexyn-300, a commercial resin that contains both strong acid and strong base groups, converted $\mathbf{1 6}$ into the cyclized product $\mathbf{4}$. High temperatures were required (sealed tube, $170{ }^{\circ} \mathrm{C}, 8 \mathrm{~h}$ ), as well as the addition of $\mathrm{Na}_{2} \mathrm{SO}_{4}$ as a water sequestering agent. In addition to $\mathbf{4}$, a small quantity of $\mathbf{1 6}$ (10\% based on $\mathbf{1 5}$ ) was recovered from the cyclization.

\section{Conclusion}

The synthesis of the model intermediate cyclohexanone $\mathbf{1 1}$ has been successfully accomplished using an alkylidene carbene insertion/ozonolysis/aldol/conjugate addition sequence. The conjugate addition to the $\alpha$-alkyl cyclohexenone proceeded with high diastereocontrol, so this strategy can be used for the construction of multi-substituted cyclohexanones. The Mannich cyclization was realized in the presence of Rexyn-300 and $\mathrm{Na}_{2} \mathrm{SO}_{4}$ at elevated temperature, by dehydration of the intermediate Mannich base 16. The synthesis of the Mannich product 4 containing the A, E, and F rings of $N$ - 
deacetyllappaconitine took 9 steps with $6.9 \%$ overall yield, starting from ketone 7. Our efforts toward the enantioselective total synthesis of $N$-deacetyllappaconitine are continuing.

\section{Experimental Section}

\section{Cyclohexanone (11)}

A mixture of $\mathrm{CuBr} \cdot \mathrm{Me}_{2} \mathrm{~S}(1.77 \mathrm{~g}, 8.6 \mathrm{mmol})$ and $\mathrm{LiCl}(364 \mathrm{mg}, 8.6 \mathrm{mmol})$ in THF (33 mL) was purged with $\mathrm{N}_{2}$ for $15 \mathrm{~min}$. The mixture was chilled to $-78^{\circ} \mathrm{C}$ and 3-butenyl magnesium bromide $(0.65 \mathrm{M}$ in THF, $13 \mathrm{~mL}, 8.45 \mathrm{mmol})$ was added. After a few min, TESCl $(1.5 \mathrm{~mL}, 8.6 \mathrm{mmol})$ was added, followed immediately by the addition of the cyclohexenone $10(1.00 \mathrm{~g}, 4.4 \mathrm{mmol})$ in THF $(0.5 \mathrm{~mL})$. The reaction mixture was stirred at $-78^{\circ} \mathrm{C}$ for $15 \mathrm{~min}$, then warmed to $-30^{\circ} \mathrm{C}$ over $0.5 \mathrm{~h}$. After stirring at $-30^{\circ} \mathrm{C}$ for $15 \mathrm{~min}$, the mixture was partitioned between saturated aqueous $\mathrm{NH}_{4} \mathrm{Cl}$ and $\mathrm{Et}_{2} \mathrm{O}$. The combined organic extract was dried $\left(\mathrm{Na}_{2} \mathrm{SO}_{4}\right)$ and concentrated. The residue was redissolved in THF $(10 \mathrm{~mL})$ and TBAF $(1.0 \mathrm{M}$ in THF, $5 \mathrm{~mL}, 5 \mathrm{mmol})$ was added. After stirring for $0.5 \mathrm{~h} \mathrm{at} \mathrm{rt}$, the mixture was partitioned between saturated aqueous $\mathrm{NH}_{4} \mathrm{Cl}$ and $\mathrm{Et}_{2} \mathrm{O}$. The combined organic extract was dried $\left(\mathrm{Na}_{2} \mathrm{SO}_{4}\right)$ and concentrated. The residue was chromatographed to afford cyclohexanone $\mathbf{1 1}$ (960 mg, $3.4 \mathrm{mmol}, 78 \%$ yield) as a colorless oil, TLC $R_{f}=0.44$ (10\% $\mathrm{Et}_{2} \mathrm{O} /$ petroleum ether); ${ }^{1} \mathrm{H}$ NMR $\left(\mathrm{CDCl}_{3}, 400 \mathrm{MHz}\right): \delta 0.79(\mathrm{~d}, J=6.7 \mathrm{~Hz}, 3 \mathrm{H}), 0.97$ (d, $J=6.4 \mathrm{~Hz}, 3 \mathrm{H}), 1.05-1.15(\mathrm{~m}, 2 \mathrm{H}), 1.39$ (s, 3H), $1.48(\mathrm{~s}, 3 \mathrm{H}), 1.83-1.96(\mathrm{~m}, 3 \mathrm{H}), 2.05-$ $2.15(\mathrm{~m}, 4 \mathrm{H}), 2.52-2.58(\mathrm{~m}, 1 \mathrm{H}), 2.82-2.90(\mathrm{~m}, 1 \mathrm{H}), 3.78-3.83(\mathrm{~m}, 2 \mathrm{H}), 4.99-5.04(\mathrm{~m}, 2 \mathrm{H})$, 5.65-5.73 $(\mathrm{m}, 1 \mathrm{H}) ;{ }^{13} \mathrm{C} \mathrm{NMR}\left(\mathrm{CDCl}_{3}, 100 \mathrm{MHz}\right): \delta$ u $116.3,110.2,82.8,73.8,35.6,34.3$, 32.5, 30.9, 6.2; d 137.9, 63.0, 46.4, 28.7, 26.6, 22.0, 21.7, 7.0; IR (cm $\left.\mathrm{cm}^{-1}\right)$ 1708, 1370, 1211, 1059; HRMS calcd for $\mathrm{C}_{17} \mathrm{H}_{28} \mathrm{O}_{3}$ (M) 280.2038, found 280.2035.

\section{Diol (14)}

To the cyclohexanone $11(500 \mathrm{mg}, 1.79 \mathrm{mmol})$ in $\mathrm{THF} / \mathrm{H}_{2} \mathrm{O}(4: 1,10 \mathrm{~mL})$ was added trifluoroacetic acid $(1 \mathrm{~mL})$. The mixture was warmed to reflux for $4 \mathrm{~h}$, and then cooled. $\mathrm{Et}_{3} \mathrm{~N}(2 \mathrm{~mL})$ was added, and the mixture was partitioned between saturated aqueous $\mathrm{NaHCO}_{3}$ and ethyl acetate. The combined organic extract was dried $\left(\mathrm{Na}_{2} \mathrm{SO}_{4}\right)$ and concentrated. The residue was chromatographed to give an inseparable mixture of diols $\mathbf{1 4}$ (2:1 mixture of diastereomers, $260 \mathrm{mg}, 1.1 \mathrm{mmol}, 68 \%$ yield based on $90 \%$ conversion) as a colorless oil, TLC $R_{f}=0.15$ (50\% Et $2 \mathrm{O} /$ petroleum ether). Starting material 11 (50 mg, 0.18 mmol, $10 \%$ ) was also recovered. For 14: ${ }^{1} \mathrm{H}$ NMR $\left(\mathrm{CDCl}_{3}, 400 \mathrm{MHz}\right): \delta 0.80$ (major) (d, $J=$ $6.7 \mathrm{~Hz}, 2$ of $3 \mathrm{H}$ ), 0.85 (minor) (d, $J=6.8 \mathrm{~Hz}, 1$ of $3 \mathrm{H}$ ), 0.92 (minor) (d, $J=6.3 \mathrm{~Hz}, 1$ of $3 \mathrm{H}), 1.00$ (major) (d, $J=6.5 \mathrm{~Hz}, 2$ of $3 \mathrm{H}), 1.02-1.07(\mathrm{~m}, 1 \mathrm{H}), 1.34-1.43(\mathrm{~m}, 1 \mathrm{H}), 1.75-2.21$ $(\mathrm{m}, 7 \mathrm{H}), 2.44(\mathrm{~s}, 1 \mathrm{H}), 2.61-2.72(\mathrm{~m}, 2 \mathrm{H}), 2.85-2.92(\mathrm{~m}, 1 \mathrm{H}), 3.50(\mathrm{t}, J=12.4 \mathrm{~Hz}, 1 \mathrm{H}), 3.64$ $(\mathrm{t}, J=12.4 \mathrm{~Hz}, 1 \mathrm{H}), 4.95-5.04(\mathrm{~m}, 2 \mathrm{H}), 5.67-5.77(\mathrm{~m}, 1 \mathrm{H}) ;{ }^{13} \mathrm{C} \mathrm{NMR}\left(\mathrm{CDCl}_{3}, 100 \mathrm{MHz}\right)$ : $\delta$ u (major): 216.6, 115.8, 73.9, 68.5, 34.8, 32.0, 31.7, 29.5; (minor): 214.4,115.3, 74.3, 67.5, 38.6, 34.3, 32.3, 25.8; d (major): 137.9, 62.3, 43.8, 29.6, 21.9, 21.8; (minor): 138.3, 56.3, 46.7, 23.6, 22.5, 19.8; IR $\left(\mathrm{cm}^{-1}\right) 3433,1693,1045$; HRMS calcd for $\mathrm{C}_{14} \mathrm{H}_{24} \mathrm{NaO}_{3}(\mathrm{M}+\mathrm{Na})$ 263.1623, found 263.1614.

\section{Monotosylate (15)}

A mixture of the diol 14 (300 mg, $1.25 \mathrm{mmol})$, DMAP (15.3 mg, $0.125 \mathrm{mmol})$, and $\mathrm{Et}_{3} \mathrm{~N}$ ( $0.52 \mathrm{~mL}, 3.75 \mathrm{mmol})$ in $\mathrm{CH}_{2} \mathrm{Cl}_{2}(6.3 \mathrm{~mL})$ was cooled to $0^{\circ} \mathrm{C}$. TsCl $(357.5 \mathrm{mg}, 1.88 \mathrm{mmol})$ was added in portions over $15 \mathrm{~min}$, and the resulting mixture was stirred at $\mathrm{rt}$ for $24 \mathrm{~h}$. The mixture was partitioned between saturated aqueous $\mathrm{NaHCO}_{3}$ and $\mathrm{Et}_{2} \mathrm{O}$ The combined organic extract was dried. $\left(\mathrm{Na}_{2} \mathrm{SO}_{4}\right)$ and then concentrated. The residue was chromatographed to provide monotosylate 15 (inseparable 2:1 mixture of diastereomers, 232 $\mathrm{mg}, 0.59 \mathrm{mmol}, 63 \%$ yield based on $75 \%$ conversion) as a colorless oil, TLC $R_{f}=0.37$ (50\% $\mathrm{Et}_{2} \mathrm{O} /$ petroleum ether). Starting material $14(75 \mathrm{mg}, 0.19 \mathrm{mmol}, 25 \%)$ was also recovered. 
For 15: ${ }^{1} \mathrm{H} \mathrm{NMR}\left(\mathrm{CDCl}_{3}, 400 \mathrm{MHz}\right): \delta 0.78$ (major) (d, $J=6.6 \mathrm{~Hz}, 2$ of $\left.3 \mathrm{H}\right), 0.81$ (minor) $(\mathrm{d}, J=6.8 \mathrm{~Hz}, 1$ of $3 \mathrm{H}), 0.90$ (minor) (d, $J=6.2 \mathrm{~Hz}, 1$ of $3 \mathrm{H}), 1.00$ (major) (d, $J=5.6 \mathrm{~Hz}, 2$ of 3H), 1.02-1.07 (m, 1H), 1.12-1.32 (m, 1H), 1.71-2.20 (m, 7H), 2.47-2.80 (m, 5H), 2.87$2.94(\mathrm{~m}, 1 \mathrm{H}), 3.92-4.03(\mathrm{~m}, 2 \mathrm{H}), 4.86-4.98(\mathrm{~m}, 2 \mathrm{H}), 5.57-5.65(\mathrm{~m}, 1 \mathrm{H}), 7.30-7.40(\mathrm{~m}, 2 \mathrm{H})$,

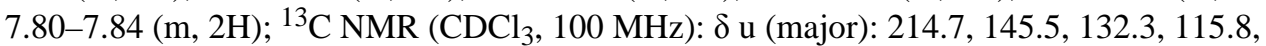
75.7, 73.0, 34.2, 31.5, 31.4, 25.9; (minor): 212.8, 145.6, 132.2, 115.3, 74.8, 73.0, 38.0, 34.1, 31.9, 29.5; d (major): 137.4, 130.2, 128.1, 61.6, 43.4, 29.5, 23.5, 21.8, 19.7; (minor): 137.6, 130.2, 128.0, 55.8, 46.9, 29.5, 22.5, 21.7, 19.7; IR (cm $\left.{ }^{-1}\right)$ 3508, 1704, 1598, 1362, 1176; HRMS calcd for $\mathrm{C}_{21} \mathrm{H}_{30} \mathrm{NaO}_{5} \mathrm{~S}(\mathrm{M}+\mathrm{Na}) 417.1712$, found 417.1720.

\section{Mannich cyclized amine (4)}

The monotosylate 15 (150 mg, $0.38 \mathrm{mmol})$ and Sudan-III $(1 \mathrm{mg})$ in $\mathrm{CH}_{2} \mathrm{Cl}_{2}(20 \mathrm{~mL})$ was chilled to $-78^{\circ} \mathrm{C}$. Ozone was passed through the solution until the pink color faded, then $\mathrm{N}_{2}$ was passed through for $15 \mathrm{~min}$. Dimethyl sulfide $(0.056 \mathrm{~mL}, 0.74 \mathrm{mmol})$ was added and the mixture was stirred for another $2 \mathrm{~h}$. The mixture was concentrated in vacuo and transferred into a thick- wall tube. THF $(1.4 \mathrm{~mL})$ was added and the mixture was purged with $\mathrm{N}_{2}$ for 15 min. Ethylamine $\left(70 \% \mathrm{H}_{2} \mathrm{O}\right.$ solution, $\left.5.6 \mathrm{~mL}\right)$ was added, and the tube was sealed and put into a $65^{\circ} \mathrm{C}$ oil bath for $4 \mathrm{~h}$. The mixture was cooled, and partitioned between $\mathrm{H}_{2} \mathrm{O}$ and ethyl acetate. The combined organic extract was dried $\left(\mathrm{Na}_{2} \mathrm{SO}_{4}\right)$, and then concentrated in vacuo. The residue was transferred into a thick-wall tube (Aldrich), and Rexyn-300 (fisher, 700 $\mathrm{mg}), \mathrm{Na}_{2} \mathrm{SO}_{4}(563 \mathrm{mg})$, and $o$-xylene $(2.8 \mathrm{~mL})$ were added. The solution was purged with $\mathrm{N}_{2}$ for $15 \mathrm{~min}$, and then the tube was sealed and put into $170^{\circ} \mathrm{C}$ oil bath for $8 \mathrm{~h}$ (safety shield!). The mixture was cooled down, and $\mathrm{Et}_{3} \mathrm{~N}(1.5 \mathrm{~mL})$ was added. The mixture was stirred for $0.5 \mathrm{~h}$ and filtered. The filter cake was washed with ethyl acetate and the filtrate was concentrated. The residue was chromatographed to give the cyclized product 4 (30 mg, $0.12 \mathrm{mmol}, 31 \%$ yield from 15$)$ as a pale yellow oil, TLC $R_{f}=0.45\left(50 \% \mathrm{Et}_{2} \mathrm{O} /\right.$ petroleum ether); ${ }^{1} \mathrm{H} \mathrm{NMR}\left(\mathrm{CDCl}_{3}, 400 \mathrm{MHz}\right): \delta 0.89(\mathrm{~d}, J=6.9 \mathrm{~Hz}, 3 \mathrm{H}), 0.95(\mathrm{t}, J=7.1 \mathrm{~Hz}, 3 \mathrm{H})$, $1.16(\mathrm{~d}, J=6.9 \mathrm{~Hz}, 3 \mathrm{H}), 1.43-1.53(\mathrm{~m}, 3 \mathrm{H}), 1.66-1.82(\mathrm{~m}, 3 \mathrm{H}), 1.96-2.05(\mathrm{~m}, 2 \mathrm{H}), 2.21-$ $2.33(\mathrm{~m}, 5 \mathrm{H}), 2.51-2.58(\mathrm{~m}, 1 \mathrm{H}), 2.69(\mathrm{~d}, J=10.8 \mathrm{~Hz}, 1 \mathrm{H}), 3.34(\mathrm{~d}, J=4.9 \mathrm{~Hz}, 1 \mathrm{H}) ;{ }^{13} \mathrm{C}$ NMR $\left(\mathrm{CDCl}_{3}, 100 \mathrm{MHz}\right): \delta$ u 214.1, 69.6, 63.7, 58.1, 48.7, 40.2, 36.6, 24.1, 19.7; d 66.6, 49.5, 30.2, 18.1, 17.5, 13.0; IR ( $\left.\mathrm{cm}^{-1}\right) 3450,1697,1153,1093$; HRMS calcd for $\mathrm{C}_{15} \mathrm{H}_{26} \mathrm{NO}_{2}(\mathrm{M}+\mathrm{H})$ 252.1964, found 252.1965.

The uncyclized Mannich base 16 (10 $\mathrm{mg}, 0.037 \mathrm{mmol}, 10 \%$ yield from 15) was also isolated, TLC $\mathrm{R}_{\mathrm{f}}=0.22\left(50 \% \mathrm{Et}_{2} \mathrm{O} /\right.$ petroleum ether $) ;{ }^{1} \mathrm{H} \mathrm{NMR}\left(\mathrm{CDCl}_{3}, 400 \mathrm{MHz}\right): \delta 0.99$ $(\mathrm{d}, J=7.1 \mathrm{~Hz}, 3 \mathrm{H}), 1.06(\mathrm{~d}, J=7.0 \mathrm{~Hz}, 3 \mathrm{H}), 1.11(\mathrm{t}, J=7.2 \mathrm{~Hz}, 3 \mathrm{H}), 1.43-1.61(\mathrm{~m}, 2 \mathrm{H})$, 1.71-1.83 (m, 3H), 1.94-2.05 (m, 4H), 2.18-2.24 (m, 2H), 2.36-2.41 (m, 2H), 2.66-2.71 $(\mathrm{m}, 1 \mathrm{H}), 2.81-2.86(\mathrm{~m}, 1 \mathrm{H}), 3.56(\mathrm{~d}, J=9.9 \mathrm{~Hz}, 1 \mathrm{H}), 4.79(\mathrm{~s}, 1 \mathrm{H}) ;{ }^{13} \mathrm{C} \mathrm{NMR}\left(\mathrm{CDCl}_{3}, 100\right.$ MHz): $\delta$ u 210.3, 81.5, 59.0, 52.0, 40.1, 35.8, 31.6, 23.7; d 93.3, 56.7, 43.9, 25.6, 20.6, 17.4, 14.6; IR ( $\left.\mathrm{cm}^{-1}\right) 3558,1715,1456,1070$; HRMS calcd for $\mathrm{C}_{15} \mathrm{H}_{25} \mathrm{NO}_{2}\left(\mathrm{M}-\mathrm{H}_{2} \mathrm{O}\right) 251.1885$, found 251.1874 .

In a separate run, chromatography after the $65^{\circ} \mathrm{C}$ heating gave 16 in $90 \%$ yield and $\mathbf{4}$ in $2 \%$ yield from 15. On exposure to the Rexyn-300 conditions, purified $\mathbf{1 6}$ gave a $30 \%$ yield of $\mathbf{4}$.

\section{Supplementary Material}

Refer to Web version on PubMed Central for supplementary material.

\section{Acknowledgments}

We thank Dr. John Dykins for recording mass spectra and the NIH (GM60287) for financial support. 


\section{References}

1. For the isolation and physiological activity of N-deacetyllappaconitine, see Chiao H, Pelletier SW, Desai HK, Rebagay WR, Caldwell RW. Eur J Pharmacol. 1995; 283:103. [PubMed: 7498298]

2. For leading references to the pharmacological activity of N-deacetyllappaconitine, see Atta-urRahman, Choudhary MI. Nat Prod Rep. 1999; 16:619. [PubMed: 10584334]

3. Further efforts have been limited to systems having two or three of the six rings of the Delphinium alkaloids. For construction of the AEF rings, see (a) Shishido K, Hiroya K, Fukumoto K, Kametani T. Tetrahedron Lett. 1986; 27:1167.For construction of the AE rings, see: (b) Callis DJ, Thomas NF, Pearson DPJ, Potter BVL. J Org Chem. 1996; 61:4634. [PubMed: 11667391] For construction of the ABE rings, see (c) Kraus GA, Dnepprovskaia E. Tetrahedron Lett. 1998; 39:2451.(d) Williams CM, Mander LN, Bernhardt PV, Willis AC. Tetrahedron. 2005; 61:3759.For construction of the ABCE rings, see (c) Williams CM, Mander LN. Org Lett. 2003; 5:3499. [PubMed: 12967309] For a review of the chemistry of the Delphinium alkaloids, see (f) Atta-ur-Rahman, Choudhary MI. Nat Prod Rep. 1995; 12:361. [PubMed: 7666978]

4. For the only total synthesis of the aconite skeleton reported to date, see (a) Wiesner K. Pure App Chem. 1979; 51:689.This synthesis was selected as one of the most important in the last century: (b) Nicolaou KC, Vourloumis D, Winssinger N, Baran PS. Angew Chem Int Ed. 2000; 39:44.

5. For reviews of the intramolecular Mannich reaction, see (a)Overman LE, Ricca DJ. Trost BM, Fleming I, Heathcock CH. Comprehensive Organic Synthesis. 2PergamonOxford1991; :1007.(b) Arend M, Westermann B, Risch N. Angew Chem Int Ed. 1998; 37:1044.For recent examples of total synthesis employing intramolecular Mannich cyclization, see (c) Paquette LA, Backhaus D, Braun R. J Am Chem Soc. 1996; 118:11990.(d) Martin SF, Barr KJ, Smith DW, Bur SK. J Am Chem Soc. 1999; 121:15284.(e) Toczko MA, Heathcock CH. J Org Chem. 2000; 65:2642. [PubMed: 10808435] (f) Kende AS, Martin Hernando JI, Milbank JBJ. Org Lett. 2001; 3:2505. [PubMed: 11483046] (g) Brueggemann M, McDonald AI, Overman LE, Rosen MD, Schwink L, Scott JP. J Am Chem Soc. 2003; 125:15284. [PubMed: 14664560]

6. Taber DF, Xu M, Hartnett JC. J Am Chem Soc. 2002; 124:13121. [PubMed: 12405840]

7. Taber DF, Cai L. J Org Chem. 2005; 70:4887. [PubMed: 15932338]

8. Barnhardt RG, McEwen WE. J Am Chem Soc. 1967; 89:7009.

9. For the development of trimethylsilyldiazomethyllithium for the cyclization of a ketone to the corresponding cyclopentene, see: (a) Ohira S, Okai K, Moritani T. J Chem Soc, Chem Commun. 1992:721.(b) Ohira S, Moritani T, Ida T, Yamato M. J Chem Soc, Chem Commun. 1993:1299.(c) Taber DF, Meagley RP. Tetrahedron Lett. 1994; 35:7909.(d) Taber DF, Walter R, Meagley RP. J Org Chem. 1994; 59:6014.(e) Ohira S, Sawamoto T, Yamato M. Tetrahedron Lett. 1995; 36:1537. (f) Taber DF, Christos TE, Hodge CN. J Org Chem. 1996; 61:2181.(g) Taber DF, Meagley RP, Doren DJ. J Org Chem. 1996; 61:5723.(h) Taber DF, Christos TE. Tetrahedron Lett. 1997; 38:4927. (i) Taber DF, Yu H, Incarvito CD, Rheingold AL. J Am Chem Soc. 1998; 120:13285.(j) Taber DF, Christos TE, Rheingold AL, Guzei IE. J Am Chem Soc. 1999; 121:5589.(k) Sakai A, Aoyama T, Shiori T. Tetrahedron Lett. 2000; 41:4927.(1) Taber DF, Storck PH. J Org Chem. 2003; 68:7768. [PubMed: 14510553]

10. Taber DF, Christos TE, Rahimizadeh M, Chen B. J Org Chem. 2001; 66:5911. [PubMed: 11511271]

11. Bobowski G, Shavel JJ. J Heterocyclic Chem. 1980; 17:519.

12. For examples of Lewis acid promoted Mannich reactions, see (a) Grieco PA, Clark JD, Jagoe CT. J Am Chem Soc. 1991; 113:5488.(b) Saidi MR, Heydari A, Ipaktschi J. Chem Ber. 1994; 127:1761. (c) Martin SF, Bur SK. Tetrahedron Lett. 1997; 38:7641.(d) Bur SK, Martin SF. Tetrahedron. 2001; 57:3221.(e) Tremblay JP, Raeppel S, Gaudette F. Tetrahedron Lett. 2004; 45:3471. 


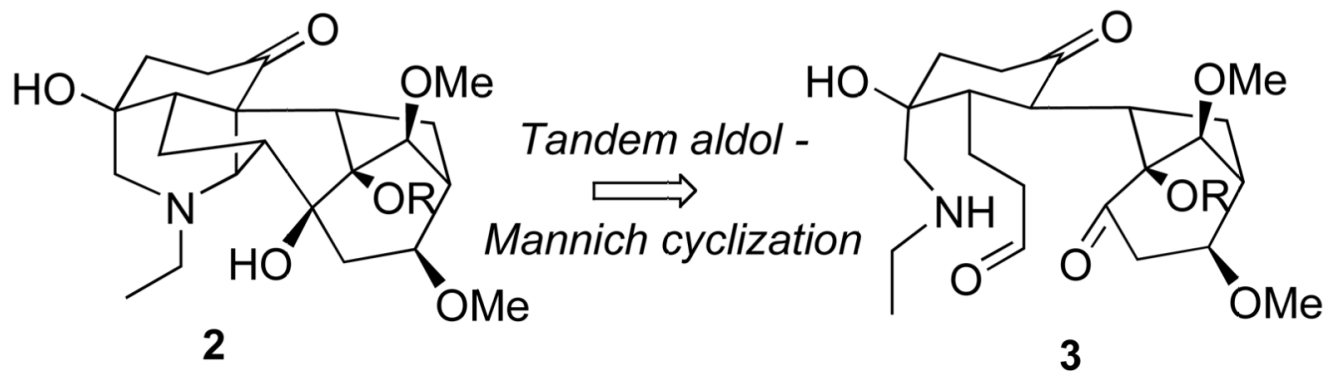

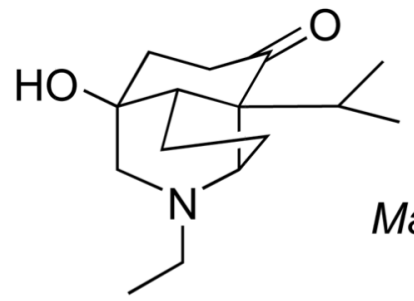

4

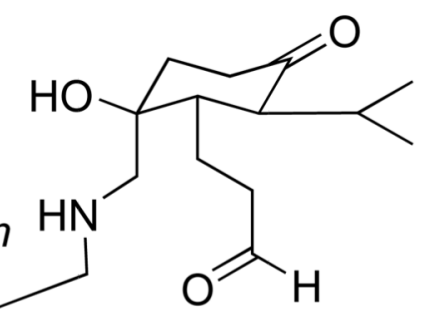

5

Scheme 1. 


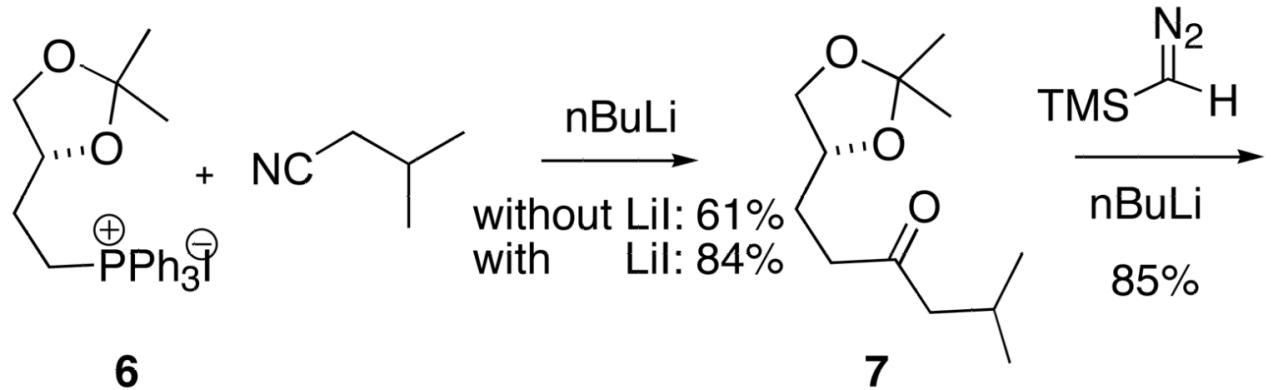<smiles>CC(C)CC1=C[C@@]2(CC1)COC(C)(C)O2</smiles>

8<smiles>CC(C)C1=C[C@]2(CCC1=O)COC(C)(C)O2</smiles>

10

Scheme 2. 


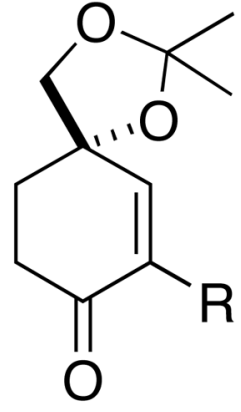

$10 \mathrm{R}=$ isopropyl

$12 \mathrm{R}=\mathrm{H}$

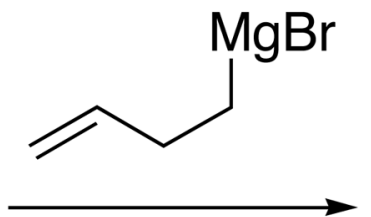

$\mathrm{CuBr} \cdot \mathrm{Me}_{2} \mathrm{~S}$, TESCI, LiCl

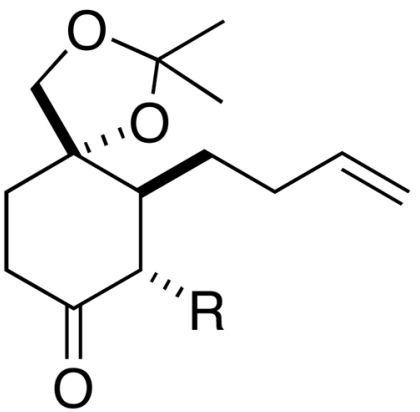

$11 \mathrm{R}=$ isopropyl

$13 \mathrm{R}=\mathrm{H}$

Scheme 3. 


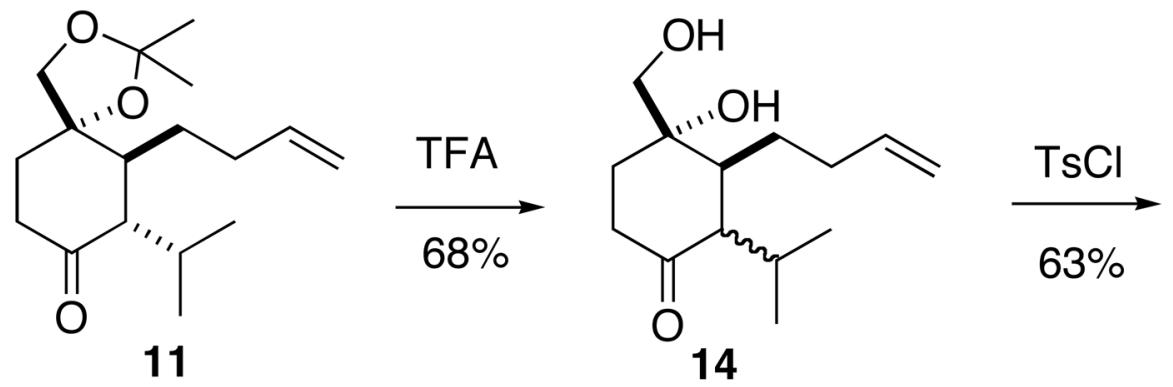<smiles>C=CCC[C@H]1[C@@H](C(C)C)C(=O)CC[C@]1(O)C[Se-]</smiles>

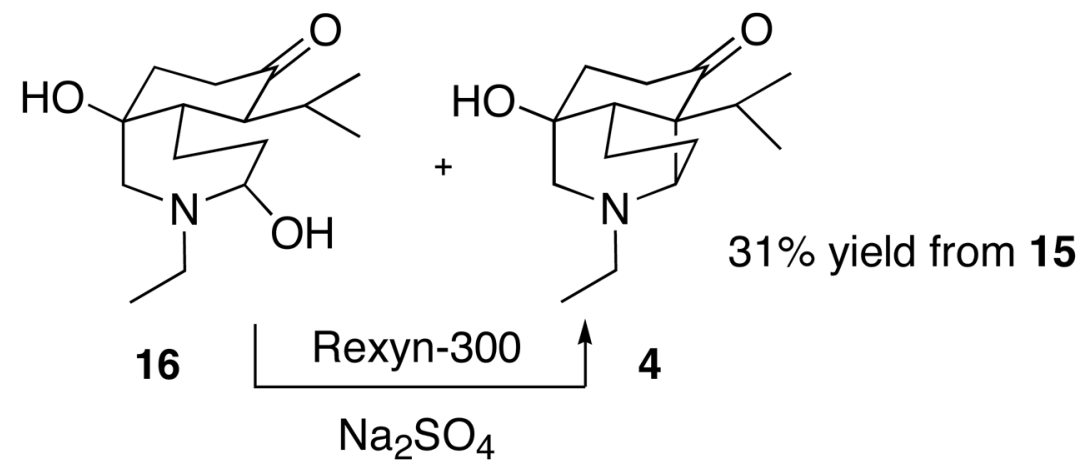

$\Delta$

Scheme 4. 